\title{
Response of Physico-Chemical Attributes in Cape Gooseberry (Physalis peruviana L.) to Integrated Nutrient Management
}

\author{
Akhilendra Verma", S.P. Singh, Akhilesh K. Pal and Bijendra Kumar Singh \\ Department of Horticulture, Institute of Agricultural Sciences, Banaras Hindu University, \\ Varanasi- 221005 (U.P.), India \\ *Corresponding author
}

\section{A B S T R A C T}

\begin{tabular}{|l|}
\hline Key w o r d s \\
Cape gooseberry, \\
Physico-chemical \\
characters, Fertilizers, \\
Farm yard manure and \\
biofertilizers.
\end{tabular}

Field experiment was conducted during 2013-14 and 2014-15 at the Horticulture Research Farm, analysed in the Laboratory Department of Horticulture, Institute of Agricultural Sciences, Banaras Hindu University, Varanasi, to study the response of physico-chemical attributes in cape gooseberry (Physalis peruviana L.) to integrated nutrient management. The experiment was laid out in Randomized Block Design with fifteen and three replications. The maximum fruit size (length and width), weight and volume were recorded in the plants treated with $100 \%$ NPK + FYM + AZB + PSB followed by $75 \%$ $\mathrm{NPK}+\mathrm{FYM}+\mathrm{AZB}+\mathrm{PSB}$ and minimum were found in the plant treated with 50\% NPK. The maximum TSS, ascorbic acid, reducing sugar, non-reducing sugar, total sugar, $\mathrm{pH}$ and TSS/Acid ratio were recorded in the fruits produced from the plants treated with $75 \%$ NPK + FYM + AZB + PSB followed by 75\% NPK + FYM + PSB. The minimum acidity was recorded in $75 \%$ NPK + FYM + AZB + PSB treated plants, whereas, the highest acidity were recorded in $100 \%$ NPK. The highest juice percent and $\mathrm{pH}$ were recorded in the $100 \%$ $\mathrm{NPK}+\mathrm{FYM}+\mathrm{AZB}+\mathrm{PSB}$ whereas, the minimum juice percent and $\mathrm{pH}$ were recorded in $50 \%$ NPK treated plants.

\section{Introduction}

The cape gooseberry (Physalis peruviana L.) which belongs to the family Solanaceae, has more than 70 species but only a few have economic value. It is native to Brazil. The cape gooseberry is an annual in temperate regions and a perennial in the tropics. It is an herbaceous, semi-shrub that is upright, perennial in subtropical zones and can grow until reaches $0.9 \mathrm{~m}$. The fruit is $4-5 \mathrm{~g}$ in weight, remains protected by a calyx and covered by a brilliant yellow peel (Mayorga, et al., 2001). In North India, the fruit ripens in February, but in South India the main crop extends from January to May. The fruit is rich in vitamins A (3,000 I.U.), C and B-complex namely (thiamine, niacin, and vitamin B 12). The fruit contains 78.9-85.5\% moisture, 0.3$1.5 \%$ protein, $0.15-0.5 \%$ fat, $11-19.6 \%$ carbohydrate, $0.4-4.9 \%$ fiber, $0.7-1 \%$ ash and pulp is composed of $1.6 \mathrm{mg} / 100 \mathrm{~g}$ carotene, 0.1-0.18 $\mathrm{mg} / 100 \mathrm{~g}$ thiamine, $0.03-0.18$ $\mathrm{mg} / 100 \mathrm{~g}$ riboflavin, $0.8-1.7 \mathrm{mg} / 100 \mathrm{~g}$ niacin, $20-43 \mathrm{mg} / 100 \mathrm{~g}$ vitamin $\mathrm{C}, 210-467 \mathrm{mg} / 100 \mathrm{~g}$ $\mathrm{K}, 7-19 \mathrm{mg} / 100 \mathrm{~g} \mathrm{Mg}, 8-28 \mathrm{mg} / 100 \mathrm{~g} \mathrm{Ca}, 27-$ $55.3 \mathrm{mg} / 100 \mathrm{~g} \mathrm{P}, 0.3-1.2 \mathrm{mg} / 100 \mathrm{~g} \mathrm{Fe}, 0.28-$ $0.40 \mathrm{mg} / 100 \mathrm{~g} \mathrm{Zn} \mathrm{(Puente} \mathrm{et} \mathrm{al.,} \mathrm{2011;}$ Ramadan and Morsel, 2009). Intensive cultivation coupled with use of unbalanced 
and inadequate fertilizers accompanied with restricted use of organic manures and biofertilizers has made the soils not only deficient in nutrients, but also deteriorated the soil health which ultimately resulted declined yield level. Under such situation, the use of chemical fertilizers along with organic manures and biofertilizers has assumed a great significance for the maintenance of soil productivity.

\section{Materials and Methods}

The present investigation entitled "Response of Physico-Chemical Attributes in Cape Gooseberry (Physalis peruviana L.) to Integrated Nutrient Management" was carried out during winter season of 2013-14 and 2014-15 at the Vegetable Research Farm, analysed in the Laboratory of Department of Horticulture, Institute of Agricultural Sciences, Banaras Hindu University, Varanasi. The treatment comprised with different doses of NPK@ 100, 80 and 60 $\mathrm{kg} / \mathrm{ha}$, farm yard manure (15 t/ha) along with bio-fertilizers (Azotobacter and PSB). Five morphological or physical characters (Table 1) and ten chemical attributes (Table 2) of fruits were used to characterizes and describe the 15 treatment of cape gooseberry. The experiment was laid out in randomized block design with fifteen treatments and three replications. Five fruit were randomly harvested from each treatment having uniform shape and size.

The fruits were weighed and volume of fruits was determined by water displacement method. The fruit size was recorded by measuring length and diameter of fruits with the help of Vernier Callipers. The TSS of pulp was determined with the help of Erma Hand Refractometer. However, the rest quality parameters such as ascorbic acid, acidity and dry-matter content were analysed by using standard methods (AOAC, 1990). Sugars were estimated by Fehling ' $A$ ' and ' $B$ ' solution method given by Lane and Eynon, 1943. The statistical analysis was done according to method given by Panse and Sukhatme (1985).

\section{Results and Discussion}

\section{Physical characters of the fruits}

In the present investigation the fruit size (length $\times$ width) was significantly increased by the use of INM. The mean data presented in Table 1 clearly revealed that maximum fruit size, weight and volume were recorded in the plants treated with $100 \%$ NPK + FYM $+\mathrm{AZB}+\mathrm{PSB}$ followed by $75 \% \mathrm{NPK}+\mathrm{FYM}$ $+\mathrm{AZB}+$ PSB. Similar results were obtained by Gajbhiye et al., (2003), Shukla et al., (2009) and Meena et al., (2014) in tomato.

The increase in fruit size, weight and volume during the present investigation might be due to an increased photosynthetic ability of plants fertilized with $100 \%$ NPK + FYM + $\mathrm{AZB}+\mathrm{PSB}$, which in turn favored and increased accumulation of dry matter. Fruit size, weight, fruit volume and specific gravity are highly correlated with dry matter content, balanced level of hormone and nitrogen fixers which are known for accumulation of dry matter and their translocation as well as synthesis of different growth regulators (Kachot et al., 2001).

\section{Chemical attributes of the fruits}

Juice, TSS, reducing sugar, non-reducing sugar, total sugar, $\mathrm{pH}$ and TSS/Acid ratio of fruits were significantly increased by adoption of INM. The mean data presented in Table 2 clearly revealed that maximum TSS, reducing sugar, non-reducing sugar, total sugar, $\mathrm{pH}$, TSS/Acid ratio and dry matter were recorded with $75 \% \mathrm{NPK}+\mathrm{FYM}+\mathrm{AZB}+\mathrm{PSB}$ followed by $75 \%$ NPK + FYM + PSB. 
Table.1 Response of physical characteristics of fruits in cape gooseberry (Physalis peruviana L.) to integrated nutrient management (mean data of two year)

\begin{tabular}{|c|c|c|c|c|c|}
\hline Name of treatments & $\begin{array}{l}\text { Fruit length } \\
\quad(\mathrm{mm})\end{array}$ & $\begin{array}{l}\text { Fruit width } \\
\qquad(\mathrm{mm})\end{array}$ & $\begin{array}{c}\text { Fruit weight } \\
\text { (g) }\end{array}$ & $\begin{array}{l}\text { Fruit volume } \\
\text { (cc) }\end{array}$ & $\begin{array}{l}\text { Specific } \\
\text { Gravity }\end{array}$ \\
\hline $50 \% \mathrm{NPK}$ & 18.50 & 21.48 & 5.723 & 5.78 & 0.991 \\
\hline $50 \% \mathrm{NPK}+\mathrm{FYM}$ & 19.08 & 21.87 & 6.178 & 6.05 & 1.022 \\
\hline $50 \% \mathrm{NPK}+\mathrm{FYM}+\mathrm{AZB}$ & 19.17 & 22.11 & 6.548 & 6.53 & 1.003 \\
\hline $50 \% \mathrm{NPK}+\mathrm{FYM}+\mathrm{PSB}$ & 20.42 & 22.61 & 6.757 & 6.53 & 1.035 \\
\hline $50 \% \mathrm{NPK}+\mathrm{FYM}+\mathrm{AZB}+\mathrm{PSB}$ & 21.20 & 23.74 & 7.457 & 7.19 & 1.038 \\
\hline $75 \%$ NPK & 20.75 & 23.02 & 6.857 & 6.99 & 0.981 \\
\hline $75 \% \mathrm{NPK}+\mathrm{FYM}$ & 21.06 & 23.16 & 7.270 & 7.08 & 1.028 \\
\hline $75 \% \mathrm{NPK}+\mathrm{FYM}+\mathrm{AZB}$ & 21.50 & 23.90 & 7.518 & 7.64 & 0.984 \\
\hline $75 \%$ NPK + FYM + PSB & 22.16 & 24.47 & 8.388 & 8.13 & 1.032 \\
\hline $75 \% \mathrm{NPK}+\mathrm{FYM}+\mathrm{AZB}+\mathrm{PSB}$ & 23.64 & 25.07 & 8.950 & 8.69 & 1.031 \\
\hline $100 \%$ NPK & 21.49 & 24.09 & 7.585 & 7.72 & 0.983 \\
\hline $100 \%$ NPK + FYM & 21.87 & 24.28 & 8.023 & 8.05 & 0.997 \\
\hline $100 \% \mathrm{NPK}+\mathrm{FYM}+\mathrm{AZB}$ & 22.42 & 24.76 & 8.343 & 8.48 & 0.984 \\
\hline $100 \% \mathrm{NPK}+\mathrm{FYM}+\mathrm{PSB}$ & 22.53 & 25.09 & 8.770 & 8.58 & 1.023 \\
\hline $100 \% \mathrm{NPK}+\mathrm{FYM}+\mathrm{AZB}+\mathrm{PSB}$ & 23.85 & 25.65 & 9.330 & 9.38 & 0.994 \\
\hline $\mathrm{CD}$ at $5 \%$ & 2.091 & 1.447 & 1.310 & 1.31 & 0.008 \\
\hline
\end{tabular}


Table.2 Response of chemical characteristics of fruits in cape gooseberry (Physalis peruviana L.) to integrated nutrient management (mean data of two year)

\begin{tabular}{|c|c|c|c|c|c|c|c|c|c|c|}
\hline Name of treatments & $\begin{array}{c}\text { Juice } \\
\%\end{array}$ & $\begin{array}{c}\text { TSS } \\
\left({ }^{0} \text { Brix }\right)\end{array}$ & $\begin{array}{c}\text { Titratable } \\
\text { acidity } \\
(\%)\end{array}$ & $\begin{array}{c}\text { Ascorbic } \\
\text { acid } \\
(\mathrm{mg} / \mathbf{1 0 0 g})\end{array}$ & $\begin{array}{l}\text { Reducing } \\
\text { Sugar }(\%)\end{array}$ & $\begin{array}{c}\text { Non } \\
\text { reducing } \\
\text { Sugar } \\
(\%)\end{array}$ & $\begin{array}{c}\text { Total } \\
\text { sugar } \\
(\%)\end{array}$ & pH & $\begin{array}{l}\text { TSS/Acid } \\
\text { ratio }(\%)\end{array}$ & $\begin{array}{c}\text { Dry } \\
\text { matter } \\
(\%)\end{array}$ \\
\hline $50 \% \mathrm{NPK}$ & 59.64 & 12.62 & 1.025 & 39.42 & 2.93 & 2.792 & 5.72 & 4.21 & 12.34 & 11.62 \\
\hline $50 \% \mathrm{NPK}+\mathrm{FYM}$ & 60.69 & 14.26 & 0.978 & 44.42 & 3.56 & 3.458 & 7.02 & 4.25 & 14.58 & 12.18 \\
\hline $50 \% \mathrm{NPK}+\mathrm{FYM}+\mathrm{AZB}$ & 61.43 & 13.87 & 1.018 & 46.49 & 3.07 & 2.938 & 6.00 & 4.17 & 13.62 & 11.65 \\
\hline $50 \% \mathrm{NPK}+\mathrm{FYM}+\mathrm{PSB}$ & 63.45 & 15.71 & 0.848 & 49.53 & 4.84 & 3.678 & 8.51 & 4.67 & 18.55 & 13.50 \\
\hline $50 \% \mathrm{NPK}+\mathrm{FYM}+\mathrm{AZB}+\mathrm{PSB}$ & 66.42 & 16.29 & 0.778 & 50.64 & 4.98 & 4.762 & 9.74 & 4.82 & 20.95 & 13.62 \\
\hline $75 \% \mathrm{NPK}$ & 62.35 & 10.54 & 1.122 & 38.57 & 2.39 & 2.245 & 4.64 & 3.74 & 9.40 & 10.44 \\
\hline $75 \% \mathrm{NPK}+\mathrm{FYM}$ & 64.98 & 14.59 & 0.957 & 42.57 & 3.77 & 3.615 & 7.38 & 4.36 & 15.26 & 12.66 \\
\hline $75 \% \mathrm{NPK}+\mathrm{FYM}+\mathrm{AZB}$ & 66.98 & 11.24 & 1.133 & 48.68 & 2.55 & 2.355 & 4.91 & 3.75 & 9.94 & 10.68 \\
\hline $75 \% \mathrm{NPK}+\mathrm{FYM}+\mathrm{PSB}$ & 68.51 & 16.40 & 0.775 & 51.69 & 5.25 & 4.955 & 10.21 & 5.02 & 21.15 & 14.55 \\
\hline $75 \% \mathrm{NPK}+\mathrm{FYM}+\mathrm{AZB}+\mathrm{PSB}$ & 69.38 & 16.80 & 0.748 & 52.68 & 5.47 & 5.263 & 10.73 & 5.08 & 22.48 & 14.83 \\
\hline $100 \%$ NPK & 62.72 & 10.75 & 1.135 & 40.02 & 2.68 & 2.550 & 5.23 & 3.94 & 9.47 & 10.60 \\
\hline $100 \% \mathrm{NPK}+\mathrm{FYM}$ & 65.57 & 13.88 & 0.998 & 45.82 & 3.27 & 3.132 & 6.40 & 4.35 & 13.91 & 11.72 \\
\hline $100 \% \mathrm{NPK}+\mathrm{FYM}+\mathrm{AZB}$ & 67.72 & 11.78 & 1.087 & 40.50 & 2.75 & 2.632 & 5.38 & 4.15 & 10.84 & 10.95 \\
\hline $100 \% \mathrm{NPK}+\mathrm{FYM}+\mathrm{PSB}$ & 70.22 & 14.67 & 0.878 & 41.94 & 4.04 & 3.842 & 7.88 & 4.42 & 16.72 & 12.95 \\
\hline $\begin{array}{l}100 \% \mathrm{NPK}+\mathrm{FYM}+\mathrm{AZB}+ \\
\mathrm{PSB}\end{array}$ & 70.73 & 12.14 & 0.832 & 40.60 & 4.49 & 4.305 & 8.80 & 4.75 & 14.60 & 13.95 \\
\hline $\mathrm{CD}$ at $5 \%$ & 1.74 & 1.59 & 0.050 & 1.92 & 0.25 & 0.154 & 0.31 & 0.43 & 1.97 & 1.72 \\
\hline
\end{tabular}


Increase in TSS, reducing sugar, non-reducing sugar, total sugar, $\mathrm{pH}$ and TSS/Acid ratio with INM application may be attributed to the quick metabolic transformation of starch and pectin into soluble compounds and rapid translocation of sugars from leaves to the developing fruits. These findings are in agreement with the results of Singh et al., (2009) in ber, Baksh et al., (2008) in guava and Rathi and Bist (2004) in pear.

The maximum titratable acidity was recorded in the fruits which received $100 \%$ NPK, whereas the minimum acidity was recorded in $75 \% \mathrm{NPK}+\mathrm{FYM}+\mathrm{AZB}+\mathrm{PSB}$. Although, there is no report in the literature to support the results, yet it can be corroborated with the findings of Singh et al., (2009), Baksh et al., (2008), Rathi and Bist (2004) and Meena et al., (2014).

The maximum content of ascorbic acid was recorded in fruits produced with $75 \% \mathrm{NPK}+$ $\mathrm{FYM}+\mathrm{AZB}+\mathrm{PSB}$ whereas, the minimum amount of ascorbic acid was recorded in $75 \%$ NPK treated plants. The respective increase in ascorbic acid content might be due to the increased efficiency of microbial inoculants to fix atmospheric nitrogen, increase in availability of phosphorous and secretion of growth promoting substances which accelerates the physiological processes like carbohydrates synthesis etc. The results obtained also got the support of the findings of Tripathi et al., (2010), Yadav et al., (2010) and Umar et al., (2009) in strawberry.

From the results obtained during the present investigation with different treatment combinations of INM on physico-chemical attributes of cape gooseberry, it is concluded that highest length, width, weight, volume, specific gravity fruit yield and juice percentage were recorded with application of $100 \%$ NPK + FYM + AZB + PSB. So far as the quality characters of cape goosebery fruits are concerned, it was observed that application of $75 \% \mathrm{NPK}+\mathrm{FYM}+\mathrm{AZB}+$ PSB exhibited highest TSS, reducing sugar, non-reducing sugar, total sugar, ascorbic acid, TSS/Acid ratio, $\mathrm{pH}$, minimum titratable acidity, and dry matter content whereas maximum titratable acidity was recorded under $75 \%$ NPK.

On the basis of above findings, it may be concluded that for getting quality fruits the plants of cape gooseberry should be fed with $100 \% \mathrm{NPK}+\mathrm{FYM}+\mathrm{AZB}+\mathrm{PSB}$ and $75 \%$ $\mathrm{NPK}+\mathrm{FYM}+\mathrm{AZB}+\mathrm{PSB}$ in the plains of Uttar Pradesh, India.

\section{References}

A. O. A. C. 1990. Official methods of analysis association of official analytical chemists. $15^{\text {th }}$ ed. Washington, D.C., USA.

Baksh H, Yadav R and Dwivedi R. 2008. Effect of INM on growth, yield attributing characters and quality of guava $c v$. Sardar. Prog. Agri., 8 (2): 141-144.

Gajbhiye R P, Sharma R R and Tewari R N. 2003. Effect of bio-fertilizers on growth and yield parameters of tomato. I. J. of Hort., 60 (4): 368-371.

Kachot N A, Malvia D D, Solanki R M and Sagrka B K. 2001. Integrated nutrient management in rainy season groundnut. I. J. Agron., 46: 516-522.

Lane J M and Eynon L. 1943. Determination of reducing sugars by means of Fehling's solution with methylene blue as internal indicator. J. Sac. Chem. Ind. 42: 3777.

Mayorga H, Knapp H, Winterhalter P, and Duque C. 2001. Glycosidically bound flavor compounds of cape gooseberry (Physalis peruviana L.). Journal of Agriculture and Food Chemistry, 49: 1904-1908. 
Meena R K, Kumar S, Maji S, Kumar D and Kumar M. 2014. Effect of organic manures and biofertilizers on growth, flowering, yield and quality of tomato $c v$. Pusa Sheetal. Inter. J. of Agri. Scie., 10 (1): 329-332.

Panse V G and Sukhatme P V. 1985. Statistical methods for Agricultural Workers, $4^{\text {th }}$ edn. ICAR, New Delhi.

Puente L A, Pinto S A, Castro E S and Cortés M. 2011. Physalis peruviana L., The multiple properties of a highly functional fruit: a review. Food Res. I., 44: 1733-1740.

Ramadan M F, and Morsel J T. 2009. Oil extractability from enzymaticallytreated goldenberry (Physalis peruviana L.) pomace: Range of operational variables. I. J. of Food Sci. and Tech., 44: 435-444.

Rathi D S and Bist L D. 2004. Inorganic fertilizers through the use of organic supplements in low chill pear $c v$. Pant Pear-18. I. J. of Hort., 61 (3): 223-225.

Shukla Y R, Thakur A K and Joshi A. 2009. Effect of inorganic and biofertilizers on yield and horticultural traits of tomato. I. J. of Hort., 66 (2): 285-287.

Singh M, Singh H K and Singh J K. 2009. Effect of INM on yield and quality of ber $c v$. Banarsi Karaka. Asian J. of Hort., 4 (1): 47-49.

Tripathi V K, Kumar N, Shukla H S and Mishra A N. 2010. Influence of Azotobacter, Azospirillum and PSB on growth, yield and quality of strawberry $c v$. Chandler, Paper presented in National Symposium on Conservation Hort., during March, 21-23, 2010 at Dehradoon, pp 198-199.

Umar I, Wali, V K, Rehman M U, Mir M. M, Banday S A and Bisati I A. 2010. Effect of Subabul (Leucaena leucocephala), Urea and biofertilizer application on growth, yield and quality of strawberry cv. Chandler. Applied Biological Res., 12: $50-54$.

Yadav S K, Khokhar U U and Yadav R P. 2010. Integrated nutrient management for strawberry cultivation. I. J. of Hort., 67 (4): 445-449.

\section{How to cite this article:}

Akhilendra Verma, S.P. Singh, Akhilesh K. Pal and Bijendra Kumar Singh. 2017. Response of Physico-Chemical Attributes in Cape Gooseberry (Physalis peruviana L.) to Integrated Nutrient Management. Int.J.Curr.Microbiol.App.Sci. 6(11): 1940-1945.

doi: https://doi.org/10.20546/ijcmas.2017.611.230 